\title{
A Miraculous Ningguo City of China and Analysis of Influencing Factors of Competitive Advantage
}

\author{
Wei Shui \\ Department of Eco-agriculture and Regional Development \\ Sichuan Agricultural University, Chengdu Sichuan 611130, China \\ \& \\ School of Geography and Planning \\ Sun Yat-Sen University, Guangzhou 510275, China \\ Tel: 86-158-2803-3646Ｅ-mail: shuiweiman@163.com
}

Received: March 31, 2011 Accepted: April 14, 2011 doi:10.5539/jgg.v3n1p207

\begin{abstract}
Ningguo City is a remote and small county in Anhui Province, China. It has created "Ningguo Miracle" since 1990s. Its general economic capacity has been ranked \#1 (the first) among all the counties or cities in Anhui Province since 2000. In order to analyze the influencing factors of competitive advantages of Ningguo City and explain "Ningguo Miracle", this article have evaluated, analyzed and classified the general economic competitiveness of 61 counties (cities) in Anhui Province in 2004, by 14 indexes of evaluation index system. The result showed that compared with other counties (cities) in Anhui Province, Ningguo City has more advantages in competition. The competitive advantage of Ningguo City is due to the productivities, the effect of the second industry and industry, and the investment of fixed assets. Then the influencing factors of Ningguo's competitiveness in terms of productivity were analyzed with authoritative data since 1990 and a log linear regression model was established by stepwise regression method. The results demonstrated that the key influencing factor of Ningguo City's competitive advantage was the change of industry structure, especially the change of manufacture structure.
\end{abstract}

Keywords: Mountain areas, Competitive advantage, Economic competitiveness, Influencing factors, Ningguo city

\section{Introduction}

Ningguo City is located in Southeastern Anhui Province, western of Zhejiang Province, eastern of Mountain Huang and is 240 kilometers far away from Hefei City. There are about 0.38 million of population in Ningguo City, the acreage of which is about 2487 square kilometers. Ningguo City is one of the key mountain cities and its general competitiveness has been ranked the top 10 in Anhui Province since 1991. In 1994, Ningguo City took the lead in Anhui Province and has been ranked one of the nation's top-100 countries/cities. From 2000, the economic general competitiveness was kept in the first place in Anhui Province and showed favorable development trend. As a result, Ningguo city has been called "Ningguo Phenomenon in mountain area".

Mountain area is one of the typical landforms and usually be the symbol of poverty. Many people felt puzzled for "Ningguo Phenomenon". Why economic miracle could be established in such a remote mountain area with non-convenient traffic? What are the competitive advantageof Ningguo City? How to learn lessons from "Ningguo Phenomenon"? Although different districts in mountain area have different status and different development ways of backgrounds and experiences (Shui et al., 2005), a case study of Ningguo City will provide one of patterns for economic development of mountain areas with similar conditions through the analysis of competitive advantages and influencing factors.

In this paper a great deal of first-hand materials and perceptual knowledge were obtained by combination of on-the-spot investigation and indoor research and collection of original data information and documents from relevant departments of local governments. Then qualitative research and quantitative research were combined to assure research objectivity and deepness. 


\section{Evaluation of general economic competitiveness of Ningguo City and primary analysis of influencing factors}

\subsection{Evaluation index system of county-level general economic competitiveness}

According to the research results from International Institute Management Development (IMD) in Lausanne, Switzerland, Centre for Competitiveness and Evaluation, Renmin University of China and Competitiveness Research Chamber in Tianjin University of Finance and Economics, general economic competitiveness is the economic operation ability for creating added value and national wealth. And the investment, deposits, ultimate need, operation of industries, costs of living and potential developments, which support added value and national wealth, were also regarded as part of general economic competitiveness. General economic competitiveness is the core competitiveness for a country (IMD, 2005; Ulengin et al., 2002; Lall, 2001; Renmin University of China, 2003; Tianjin University of Finance \& Economics, 2004). For the limitation of official data information, we could only evaluate general economic competitiveness of a county, which is regarded as core regional competitiveness. According to the theory of regional general economic competitiveness, referring to evaluation index system of international competitiveness of IMD and considering differences between of county-level and country-level competitiveness and development stage of regional economy, 14 indexes were used to evaluate general economic competitiveness of 61 counties/cities in Anhui Province.

General economic competitiveness was analyzed from five views, e.g. added value, investment, consumption, performance of economic sector and the quality of life. Added value was reflected by gross domestic product (GDP) and GDP per capita. Investment was reflected by capital asset investment, the proportion of capital asset in GDP and capital asset investment per capita. Consumption was reflected by total volume of retail sales of social consumer goods and amount of social consumer goods per capita. Performance of economic sector was reflected by proportion of secondary industry in GDP, proportion of tertiary industry in GDP, added value of industry, added value of industry per capita and total value of agriculture, forestry, pasture and fisheries per capita. The quality of life was reflected by average salary of worker and farmers' net income per capita.

\subsection{Evaluation of general economic competitiveness of 61 counties/cities in Anhui Province}

The principal component analysis (PCA) method was used to evaluate general economic competitiveness of 61 counties/cities in Anhui Province in 2004 and discuss the competitive advantage and the position of Ningguo City within Anhui Province. The original index variables were standardized and the principal components were analyzed. Selection criteria of the 6 principal components was set as eigenvalue $(>0.6)$. The accumulative contribution rate was up to $91.42 \%$, which roughly reflected $91.42 \%$ of the original information. However, the information included in the later 8 factors was only $8.58 \%$ of the original information. Therefore the first 6 factors were used as principal components instead of 14 indexes. Coefficient matrix was established according to scores of the principal components which were calculated by regression method. Evaluation function of general economic competitiveness (as following) was constructed by scores of the principal components with variance contribution rate of principal components as weight (Shui and Chen, 2005).

$$
F=0.412 y_{1}+0.189 y_{2}+0.101 y_{3}+0.096 y_{4}+0.074 y_{5}+0.044 y_{6}
$$

Where $F$ is General economic competitiveness, $y_{i}(i=1,2 \ldots .6)$ is score of the i principal component. Based on the above function, the general economic competitiveness and ranking orders of 61 counties/cities in Anhui Province in 2004 can be obtained.

\subsection{Analysis on general economic competitiveness of Ningguo city and influencing factors}

The economic meaning of principal components and their quantitative relation with internal key indexes were studied by rotated factor loading matrix (Chen and Chen, 2002). The factor loading matrix in this paper showed that: (1) the first principal component mainly reflected regional productivity levels and economic benefit of secondary industry and industrial sector, which was named economic performance index; (2) the second principal component mainly reflected investment, named investment index; (3) the third principal component named economic scale index mainly reflected gross scale of GDP, industry, consumption and investment; (4) the forth principal component mainly reflected status of income and consumption per capita, named income and consumption per capita index; (5) the fifth principal component was named agricultural economic benefit index; (6) the sixth principal component was named tertiary industry economic benefit index. Therefore, general economic competitiveness of county could be reflected by the above six indexes. The index scores and ranking orders of Ningguo City in counties of Anhui Province could be calculated (Table 1). From Table 1, we could see that Ningguo City performed well in economic performance, investment and agricultural economic benefit. The economic scale and tertiary industry were slightly worse, whereas income and consumption per capita was the 
worst among the six indexes. Economic performance index and investment index reflected $41.2 \%$ and $18.9 \%$ of original information respectively and reflected $66 \%$ of general economic competitiveness information. This is the reason why general economic competitiveness of Ningguo City could keep the "king position" in Anhui Province. The general economic competitiveness and economic performance index were about 2.66 and 2.12 times of the second ranking city in Anhui Province.

The administration unit at county level in Anhui Province was ranked three levels by Q cluster analysis incorporrated with general economic competitiveness index, economic performance index, investment index and economic scale index, which reflected $70.1 \%$ of original information (Table 2). From Table 2, Ningguo City was ranked the first-class of three clusters for its obvious competitiveness advantages. The ranking orders of general economic competitiveness of counties ranked in class II were from the second to eighth. These counties has advantages of location, which generally located in "Wanjiang economic belts" and along Jinghu railway, influenced by Hefei metropolitan, Nanjing metropolitan and Mawutong cities' cluster.

From the above analysis, it can be seen that the advantages of economic competitiveness mainly derived from economic performance and investment. The economic performance was reflected by GDP per capita, industrial added value per capita and proportion of secondary industry. This roughly demonstrated that the secondary industry of Ningguo City, especially industry, play an important role in economy. The proportion of tertiary industry as a principle component also played a non-ignorable role in economy of Ningguo City. However, the prominent competitive advantages should be further analyzed to find the influencing factors of competitive advantages.

\section{Further analysis of competitive advantage influencing factors of Ningguo City}

\subsection{Establishment of influence function of Ningguo's competitive advantages}

Professor Porter (1990), who came from Harvard Business School, defined national competitiveness as productivity, and he think that the wealth of a country depended on its productivity. For the difficulties to collect statistical data, we use Porter's definition of competitiveness, which was indicated by GDP per capita in an area (Zhang, 2002). Influence function of Ningguo's competitive advantage was established according to the actual situation of Ningguo City and with analytical framework of influencing factors of economic development reported by Prof. Xie (2003).

$$
Y=f\left(x_{1}, x_{2}, x_{3}, x_{4}\right)
$$

Where $\mathrm{Y}$ is GDP per capita in an area, $x_{1}, x_{2}, x_{3}, x_{4}$ respectively denote proportion of secondary industry, tertiary industry, industrialization rate and urbanization level. Industrialization rate was ratio of added value of manufacture to GDP in an area. This may remove the influence of connate factors such as mining industry. Urbanization level was the ratio of urban population and total population. The annual urban population was adjusted linearly according to ratio of urban population to non agricultural population in the fifth national census documents of Ningguo City. The asset investment was not used as a variable included in function, for no information about this was obtained.

\subsection{Partial correlation analysis}

In order to find real relation between the two variables, the relations among GDP per capita in an area from 1991 to 2004, the proportion of secondary industry, the proportion of tertiary industry, industrialization rate and urbanization level were sustained partial correlation analysis and got the following function (Table 3).

The results of partial correlation analysis showed that there was good relation between the proportion of secondary industry, the proportion of tertiary industry, industrialization rate and urbanization level and GDP per capita in an area. GDP per capita in an area was less relevant to urbanization level for the coefficient of partial correlation is 0.377 . But, the significance probability is more than 0.05 . Therefore, this means there was no correlation between the two factors. From the partial correlation analysis of secondary industry, tertiary industry, industrialization rate and urbanization level, no correlation existed in these factors except proportion of tertiary industry and industrialization rate showed negative correlation.

\subsection{Stepwise regression analysis}

In order to further analyze influence degree of industrial structure, industrialization rate and urbanization level on economy, we used the related datum of Ningguo City from 1991 to 2004 to analyze GDP per capita by logarithmic regression analysis method, with GDP per capita as dependent variable, the proportion of secondary 
industry, the proportion of tertiary industry, industrialization rate and urbanization level as independent variable.

(1) Postulate detection of multiple regressions

We do not know if a linear regression model coincides with the datum. Therefore, datum should be tested, deviation should be independent, datum must meet the linear hypothesis and the datum sample should be equivalent variance (Ruan, 2005). Independence of variance and normality of residuals could be analyzed in model summary table (Table 4) and normal probability plot of residuals (Figure 1), respectively.

As statistic to test deviation independence, Durbin-Watson was assigned $0-4$. When $\mathrm{D} \approx 2$, residual and independent variable were independent with each other; When $\mathrm{D}<2$, the two adjacent residuals were positive correlation; When $\mathrm{D}>2$, the two adjacent residuals were negative correlation (Ruan, 2005). From the model summary, when Durbin-Watson=1.714 $(\approx 2)$, residuals were independent with each other. The same results were obtained from P-P plot.

(2) Establishment of multiple regression equation

The GDP per capital was logarithm regressions analyzed by stepwise regression method, with proportion of secondary industry and tertiary industry, industrialization rate and urbanization level as independent variables. The analysis of the function was as following:

i) $H_{0}$ (Hypothesis): Invalid regression model $\left(B_{1}=B_{2}=\ldots=B_{n}=0\right)$

ii) Observe variance analysis table outputted by regressions (Table 5), the $\operatorname{Sig}<\alpha(0.05)$ (Pin was assigned as $0.05)$. The original hypothesis was denied, which means the regression model was valid.

From coefficient table (Table 6), we can see that the significance levels of Ln (proportion of secondary industry), $\mathrm{Ln}$ (industrialization rate) and $\mathrm{Ln}$ (proportion of tertiary industry) were less than $\alpha(0.05)$. This demonstrated that all of the three variables related with Ln (GDP per capita). Therefore, they could not be omitted from the function, then get the valid regression model.

Iii) Observe the urbanization level variable, which was not included in the function: Partial value was $0.263<3.84$ (Fin was assigned as 3.84) and the Sig value was more than 0.05 (Pin was assigned as 0.05). Therefore, this variable could not be included in the function (Table 7).

iv) From the above analysis, we got the multiple stepwise regression model

$$
\begin{gathered}
\operatorname{Ln} Y=-19.598+2.023 \operatorname{Ln} X_{1}+3.923 \operatorname{Ln} X_{2}+2.269 \operatorname{Ln} X_{3} \\
R^{2}=0.955 \quad F=70.08 \quad \text { Sigf }<0.05
\end{gathered}
$$

Where $Y$ represents GDP per capita, $X_{1}$ is for Proportion of secondary industry, $X_{2}$ is for Industrialization rate, $X_{3}$ is for proportion of tertiary industry. The regression result demonstrated that the regression model is very significant. Industrialization rate, especially manufacture, affected competitiveness most; the second were proportion of secondary and tertiary industry. The urbanization level showed no correlation with competitiveness (under condition of default significance value). This means urbanization level hardly affect GDP per capita. Therefore, the end results showed that change of industry structure of Ningguo City is the key influencing factor of regional competitive advantages, especially the change of manufacture in industry structure.

\section{Conclusion}

By evaluation of general economic competitiveness of counties in Anhui Province and analyses of competitiveness influencing factors of Ningguo City, we concluded that the remote Ningguo City has salient competitive advantages compared with other counties/cities in Anhui Province. The advantages mainly derived from productivity, economic benefit of secondary industry and asset investment. Further analysis of influencing factors of productivity competitiveness demonstrated that the change of industry structure is the key influencing factor of Ningguo's competitive advantages, especially the change of manufacture in industry structure. This conclusion coincided with the reality of Ningguo City, explained the mystery of "Ningguo Miracle" and could be as pattern for county economic development in China. However, this is only quantitative analysis in macroscopic view. There are many other influencing factors of Ningguo's competitive advantages. But some of the important influencing factors, such as local government, culture and social assets, were difficult to be quantified. This drove us to do further competitiveness analyses of manufacture and enterprise clusters to find the micro-mechanisms of Ningguo's competitive advantages.

\section{Reference}


Chen, H. E. \& Chen, G. (2002). An Evaluating Model and Case Study on the competence of Regional Industry. China Soft Science, 1, 99-104.

IMD. (2005). The Year of Competitiveness [EB/OL]. http://www02.imd.ch/wcc.

Lall S. (2001). Competitiveness indices and developing countries:an economic evalution of the global competitiveness report. World Development, 29(9), 1501-1525. doi:10.1016/S0305-750X(01)00051-1, ttp://dx.doi.org/10.1016/S0305-750X(01)00051-1

Niu, C. Y. Economic and Social Development of Ningguo. http://www.nggcc.com/ReadNews.asp? NewsID=806.

Porter, M. E. (1990). The competitive advantage of nations. Harvard Business Review, 68, 73-93.

Renmin University of China. (2003). A Report on China International competitiveness. China Renmin University Press.

Ruan, H. G. (2005). Datum Statistic and Analysis. Beijing University Press.

Shui, W. \& Chen, L. (2005). The Application of Principal Component Analysis in the Planning of Spatial Arrangement of County Town System-With Longchuan County in Guangdong Province as an Example, Planners, 21(9), 83-87.

Shui, W., Chen, L. \& Zhang, Q.C. (2005). The Industrialization Driving Mechanism for Urbanization in Mountainous Ecological County:A Case Study of Shixing County in the Mountain Area of North Guangdong. Tropical Geography, 24, 11-16.

Tianjin University of Finance \& Economics. (2004). A Report on China Regional competitiveness (1985-2004). China statistics Press.

Ulengin, F., Ulengin, B. \& Onsel, S.A. (2002). Power-based measurement approach to specify macroeconomic competiveness of countries. Socio-Economic Planning Sciences, 36, 203-226. doi:10.1016/S0038-0121(01)00021-0, ttp://dx.doi.org/10.1016/S0038-0121(01)00021-0

Xie, J. (2003). Analysis on Change in Economic Structure and Regional Economic Difference. China Industrial Economy, 11, 78-84.

Zhang, J.C. (2002). The Theory and Method on International Competitiveness Appraisement. Economics Science Press

Table 1. The general economic competitiveness, the scores of the indexes and the order in Auhui Province of Ningguo City

\begin{tabular}{|c|c|c|c|c|c|c|c|}
\hline & $\begin{array}{c}\text { General } \\
\text { economic } \\
\text { competitiveness }\end{array}$ & $\begin{array}{c}\text { Economic } \\
\text { performance } \\
\text { index }\end{array}$ & $\begin{array}{c}\text { Investment } \\
\text { index }\end{array}$ & $\begin{array}{c}\text { Economic } \\
\text { scale } \\
\text { index }\end{array}$ & $\begin{array}{c}\text { Income and } \\
\text { consumption } \\
\text { per capita } \\
\text { index }\end{array}$ & $\begin{array}{c}\text { Agricultural } \\
\text { economic } \\
\text { benefit } \\
\text { index }\end{array}$ & $\begin{array}{c}\text { Tertiary } \\
\text { industry } \\
\text { economic } \\
\text { benefit } \\
\text { index }\end{array}$ \\
\hline Scores & 2.54 & 4.79 & 1.7 & 1.08 & -0.31 & 1.67 & 0.92 \\
\hline Orders & 1 & 1 & 3 & 8 & 36 & 3 & 11 \\
\hline
\end{tabular}


Table 2. The hierarchical clustering of the general economic competitiveness of 61 counties in Anhui Province

\begin{tabular}{|l|l|}
\hline \multicolumn{1}{|c|}{ Rank } & \multicolumn{1}{c|}{ Name of counties/cities } \\
\hline Class I & Ningguo City \\
\hline Class II & $\begin{array}{l}\text { Tianchang City, Fengtai County, Tongcheng City, Feidong County, Fanchang County, } \\
\text { Huoshan County, Wuwei County }\end{array}$ \\
\hline Class III & $\begin{array}{l}\text { Changfeng County, Feixi County, Suixi County, Woyang County, Mengcheng County, Lixin } \\
\text { County, Dangshan County, Xiao County, Lingbi County, Si County, Huaiyuan County, Wuhe } \\
\text { County, Guzhen County, Jieshou City, Linquan County, Taihe County, Funan County, } \\
\text { Yingshang County, Mingguang County, Laian County, Quanjiao County, Dingyuan County, } \\
\text { Fengyang County, Shou County, Huoqiu County, Shucheng County, Jinzhai County, Dangtu } \\
\text { County, Lujiang County, Hanshan County, He County, Wuhu County, Nanling County, Langxi } \\
\text { County, Guangde County, Jing County, Jingde County, Jixi County, Tongling County, Dongzhi } \\
\text { County, Shitai County, Qingyang County, Huaining County, Zongyang County, Qianshan } \\
\text { County, Taihu County, Susong County, Wangjiang County, Yuexi County, Xi County, Xiuning } \\
\text { County and Yi County }\end{array}$ \\
\hline
\end{tabular}

Table 3. Coefficient of partial correlation

\begin{tabular}{|c|c|c|c|c|c|}
\hline & $\begin{array}{l}\text { GDP per } \\
\text { capita }\end{array}$ & $\begin{array}{c}\text { Proportion of } \\
\text { secondary industry }\end{array}$ & $\begin{array}{l}\text { Proportion of } \\
\text { tertiary industry }\end{array}$ & $\begin{array}{l}\text { Industrialization } \\
\text { rate }\end{array}$ & $\begin{array}{c}\text { Urbanization } \\
\text { level }\end{array}$ \\
\hline GDP per capita & & $\begin{array}{c}0.7921 \\
\mathrm{P}=0.002\end{array}$ & $\begin{array}{c}0.5561 \\
\mathrm{P}=0.038\end{array}$ & $\begin{array}{c}0.5379 \\
\mathrm{P}=0.044\end{array}$ & $\begin{array}{c}0.377 \\
\mathrm{P}=0.127\end{array}$ \\
\hline $\begin{array}{c}\text { Proportion of } \\
\text { secondary industry }\end{array}$ & $\begin{array}{c}0.7921 \\
\mathrm{P}=0.002\end{array}$ & & $\begin{array}{l}-0.1494 \\
P=0.661\end{array}$ & $\begin{array}{c}-0.1317 \\
\mathrm{P}=0.7\end{array}$ & $\begin{array}{l}-0.1239 \\
P=0.717\end{array}$ \\
\hline $\begin{array}{l}\text { Proportion of } \\
\text { tertiary industry }\end{array}$ & $\begin{array}{c}0.5561 \\
\mathrm{P}=0.038\end{array}$ & $\begin{array}{l}-0.1494 \\
P=0.661\end{array}$ & & $\begin{array}{c}-0.83 \\
\mathrm{P}=0.002\end{array}$ & $\begin{array}{c}0.1835 \\
\mathrm{P}=0.589\end{array}$ \\
\hline $\begin{array}{l}\text { Industrialization } \\
\text { rate }\end{array}$ & $\begin{array}{c}0.5379 \\
\mathrm{P}=0.044\end{array}$ & $\begin{array}{l}-0.1317 \\
P=0.7\end{array}$ & $\begin{array}{c}-0.83 \\
\mathrm{P}=0.002\end{array}$ & & $\begin{array}{c}0.062 \\
\mathrm{P}=0.856\end{array}$ \\
\hline Urbanization level & $\begin{array}{c}0.377 \\
\mathrm{P}=0.127\end{array}$ & $\begin{array}{l}-0.1239 \\
\mathrm{P}=0.717\end{array}$ & $\begin{array}{c}0.1835 \\
\mathrm{P}=0.589\end{array}$ & $\begin{array}{c}0.062 \\
\mathrm{P}=0.856\end{array}$ & \\
\hline
\end{tabular}

P: Associated probability of statistical test was unilateral significance test. The degree of freedom was 9

Table 4. Model summary

\begin{tabular}{|c|c|c|c|c|}
\hline Model & R & R Square & Adjusted R Square & Durbin-Watson \\
\hline 1 & $.935(\mathrm{a})$ & .875 & .864 & \\
\hline 2 & $.961(\mathrm{~b})$ & .924 & .910 & \\
\hline 3 & $.977(\mathrm{c})$ & .955 & .941 & 1.714 \\
\hline
\end{tabular}

Model 1: Regression model with Ln (proportion of secondary industry) as independent variable; Model 2: Regression model with Ln (proportion of secondary industry) and Ln (industrialization rate) as independent variable; Model 3: Regression model with Ln (proportion of secondary industry), Ln (industrialization rate) and $\mathrm{Ln}$ (proportion of tertiary industry) as independent variable, the dependent variable was Ln (GDP per capita). 
Table 5. Variance analyses

\begin{tabular}{|c|c|c|c|c|c|c|}
\hline \multicolumn{2}{|r|}{ Model } & Sum of Squares & $\mathrm{df}$ & Mean Square & $F$ & Sig. \\
\hline \multirow[t]{3}{*}{1} & Regression & 4.330 & 1 & 4.330 & 83.649 & $.000(a)$ \\
\hline & Residual & .621 & 12 & .052 & & \\
\hline & Total & 4.952 & 13 & & & \\
\hline \multirow[t]{3}{*}{2} & Regression & 4.577 & 2 & 2.288 & 67.104 & $.000(\mathrm{~b})$ \\
\hline & Residual & .375 & 11 & .034 & & \\
\hline & Total & 4.952 & 13 & & & \\
\hline \multirow[t]{3}{*}{3} & Regression & 4.727 & 3 & 1.576 & 70.084 & $.000(\mathrm{c})$ \\
\hline & Residual & .225 & 10 & .022 & & \\
\hline & Total & 4.952 & 13 & & & \\
\hline
\end{tabular}

Table 6. Coefficient analysis

\begin{tabular}{|c|c|c|c|c|c|c|}
\hline & \multirow{2}{*}{ Model } & \multicolumn{2}{|c|}{ Unstandardized Coefficients } & \multirow{2}{*}{$\begin{array}{c}\begin{array}{c}\text { Standardized } \\
\text { Coefficients }\end{array} \\
\text { Beta }\end{array}$} & \multirow[t]{2}{*}{$\mathrm{t}$} & \multirow[t]{2}{*}{ Sig. } \\
\hline & & B & Std. Error & & & \\
\hline \multirow[b]{2}{*}{1} & (Constant) & -7.029 & 1.731 & & -4.061 & .002 \\
\hline & $\begin{array}{c}\text { Ln (Proportion of secondary } \\
\text { industry) }\end{array}$ & 4.290 & .469 & .935 & 9.146 & .000 \\
\hline \multirow{3}{*}{2} & (Constant) & -12.293 & 2.411 & & -5.099 & .000 \\
\hline & $\begin{array}{c}\text { Ln (Proportion of secondary } \\
\text { industry) }\end{array}$ & 3.798 & .422 & .828 & 8.990 & .000 \\
\hline & Ln (Industrialization rate) & 2.080 & .774 & .247 & 2.687 & .021 \\
\hline \multirow{4}{*}{3} & (Constant) & -19.598 & 3.437 & & -5.702 & .000 \\
\hline & $\begin{array}{c}\text { Ln (Proportion of secondary } \\
\text { industry) }\end{array}$ & 2.023 & .768 & .441 & 2.635 & .025 \\
\hline & Ln (Industrialization rate) & 3.923 & .950 & .467 & 4.128 & .002 \\
\hline & $\begin{array}{c}\text { Ln (Proportion of tertiary } \\
\text { industry) }\end{array}$ & 2.269 & .878 & .393 & 2.586 & .027 \\
\hline
\end{tabular}

Dependent variable wan Ln (GDP per capita)

Table 7. Excluded variables

\begin{tabular}{|c|c|c|c|c|c|c|}
\hline \multicolumn{2}{|c|}{ Model } & Beta In & $\mathrm{t}$ & Sig. & Partial Correlation & Collinearity Statistics \\
\hline \multirow{3}{*}{1} & $\begin{array}{c}\text { Ln (Proportion of tertiary } \\
\text { industry) }\end{array}$ & $-.078(\mathrm{a})$ & -.491 & .633 & -.147 & .448 \\
\cline { 2 - 7 } & Ln (Urbanization level) & $.218(\mathrm{a})$ & 1.064 & .310 & .306 & .247 \\
\cline { 2 - 7 } & Ln (Industrialization rate) & $.247(\mathrm{a})$ & 2.687 & .021 & .629 & .812 \\
\hline \multirow{2}{*}{2} & $\begin{array}{c}\text { Ln (Proportion of tertiary } \\
\text { industry) }\end{array}$ & $.393(\mathrm{~b})$ & 2.586 & .027 & .633 & .196 \\
\cline { 2 - 7 } & Ln (Urbanization level) & $.271(\mathrm{~b})$ & 1.757 & .109 & .486 & .244 \\
\hline 3 & Ln (Urbanization level) & $.130(\mathrm{c})$ & .818 & .434 & .263 & .186 \\
\hline
\end{tabular}




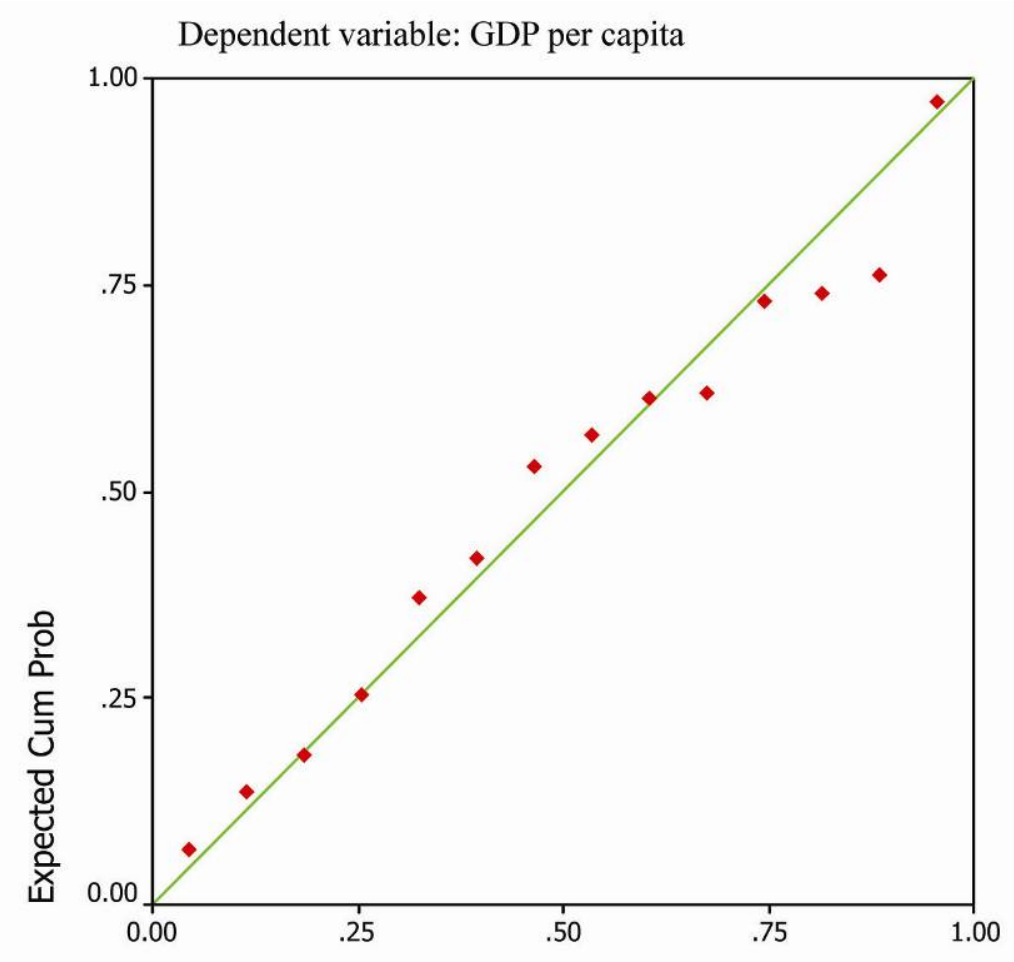

Figure 1. Normal P-P plot of regression standardized residual 